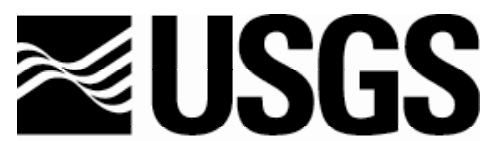

science for a changing world

\title{
Direct Current Resistivity Profiling to Study Distribution of Water in the Unsaturated Zone Near the Amargosa Desert Research Site, Nevada
}

By Jared D. Abraham and Jeffrey E. Lucius

Any use of trade, firm, or product names is for descriptive purposes only and does not imply endorsement by the U.S. Government

Open-File Report 2004-1319

U.S. Department of the Interior

U.S. Geological Survey 


\section{U.S. Department of the Interior \\ Gale A. Norton, Secretary \\ U.S. Geological Survey \\ Charles G. Groat, Director}

U.S. Geological Survey, Reston, Virginia 2004

Revised and reprinted: 2004

For product and ordering information:

World Wide Web: http://www.usgs.gov/pubprod

Telephone: 1-888-ASK-USGS

For more information on the USGS-the Federal source for science about the Earth, its natural and living resources, natural hazards, and the environment:

World Wide Web: http://www.usgs.gov

Telephone: 1-888-ASK-USGS

Although this report is in the public domain, permission must be secured from the individual copyright owners to reproduce any copyrighted material contained within this report. 


\section{Contents}

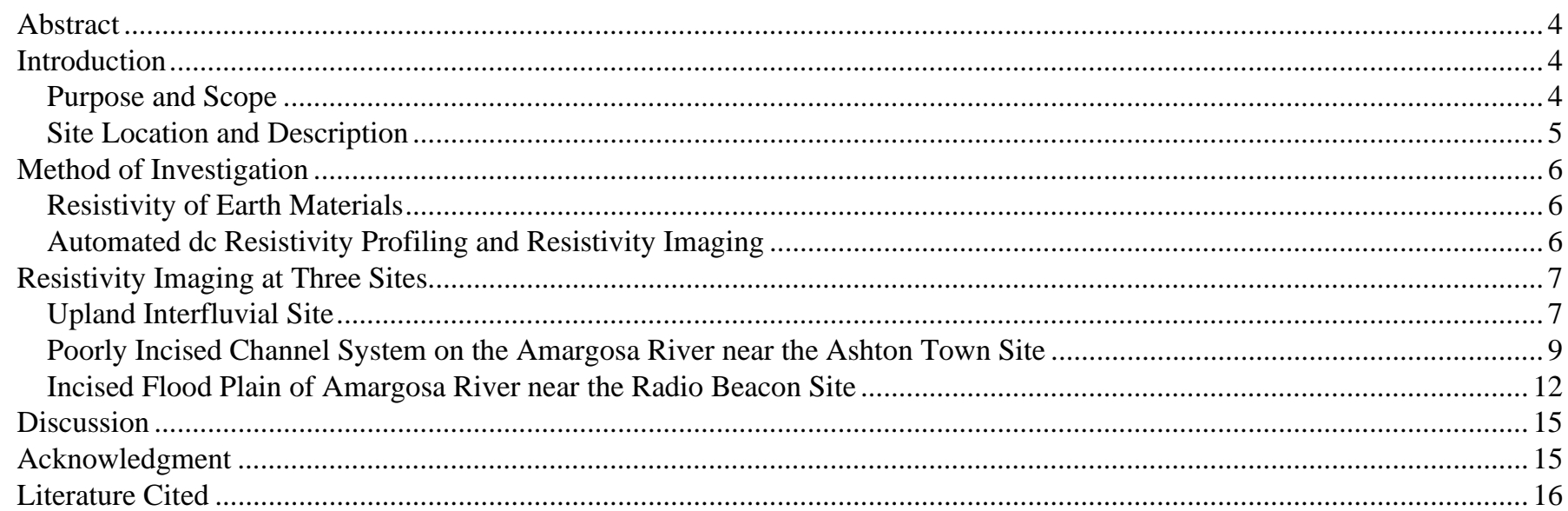

\section{Figures}

Figure 1. Locations of the Amargosa Desert Research Site, waste-storage facility, and the three profiles for dc resistivity profiling, northern Amargosa Desert, Nevada.

Figure 2. View of the dc resistivity profile along the seismic refraction-reflection line across the southern end of the ADRS, Amargosa Desert, Nevada.

Figure 3. Resistivity imaging at the upland interfluvial site near the southern end of the ADRS, Amargosa Desert, Nevada. (a) The field apparent resistivity calculations shown as a pseudosection. (b) The inversion model resistivity calculations shown as a pseudosection. (c) The resistivity cross section derived from the inversion. .................................................. 8

Figure 4. Resistivity cross section for the Upland Interfluvial Site at the south end of the ADRS, Amargosa Desert, Nevada. ... 9

Figure 5. A view looking across the de resistivity profile and down one of the poorly incised (distributary) channel systems of the Amargosa River near the town site of Ashton, Amargosa Desert, Nevada.

Figure 6. Resistivity imaging at the poorly incised Amargosa River channel system near the town site of Ashton, Amargosa Desert, Nevada. (a) The field apparent resistivity calculations shown as a pseudosection. (b) The inversion model resistivity calculations shown as a pseudosection. (c) The resistivity cross section derived from the inversion.

Figure 7. The resistivity cross section for the poorly incised Amargosa River channel system near Ashton town site south of the ADRS, Amargosa Desert, Nevada.

Figure 8. A view from the west side of the incised channel of the Amargosa River near the aviation navigation radio beacon northwest of the ADRS, Amargosa Desert, Nevada..

Figure 9. Resistivity imaging at the well-incised flood plain of the Amargosa River near the aviation navigational radio beacon northwest of the ADRS, Amargosa Desert, Nevada. (a) The field apparent resistivity calculations shown as a pseu dosection. (b) The inversion model resistivity calculations shown as a pseudosection. (c) The resistivity cross section derived from the inversion.

Figure 10. The resistivity cross section at the well-incised flood plain of the Amargosa River near the aviation navigational radio beacon northwest of the ADRS, Amargosa Desert, Nevada. 


\title{
Direct Current Resistivity Profiling to Study Distribution of Water in the Unsaturated Zone Near the Amargosa Desert Research Site, Nevada
}

\author{
By Jared D. Abraham and Jeffrey E. Lucius
}

\section{Abstract}

In order to study the distribution of water in the unsaturated zone and potential for ground-water recharge near the Amargosa Desert Research Site south of Beatty, Nevada, the U.S. Geological Survey collected direct-current resistivity measurements along three profiles in May 2003 using an eight-channel resistivity imaging system. Resistivity data were collected along profiles across the ADRS, across a poorly incised (distributary) channel system of the Amargosa River southwest of the ADRS, and across a well-incised flood plain of the Amargosa River northwest of the ADRS. Subsurface profiles of resistivity produced from these data indicate three categories of materials:

1. laterally extensive very-dry, high-resistivity $(>150 \mathrm{ohm}-\mathrm{m})$ materials at the surface,

2. localized regions of higher-water content, and lower-resistivity $(<40 \mathrm{ohm}-\mathrm{m})$ materials below the surface in active recharge areas (beneath the Amargosa River), and

3. laterally extensive areas of intermediate water content and resistivity values.

In addition, data at the ADRS show the gradual thickening of alluvial fill (mostly sand and gravel) into the valley. The resistivity cross sections complement and extend borehole and surface studies of spatial and temporal subsurface water flow and help to define thickness and extent of distinct alluvial layers. Future investigations are planned to study the correlation of apparent resistivity with moisture and salt content for the ADRS area.

\section{Introduction}

As part of the U.S. Geological Survey's (USGS) Toxic Substances Hydrology Program, the Amargosa Desert Research Site (ADRS) is a field site in the northern Amargosa Desert about 17 kilometers (km) south of Beatty, Nevada (fig. 1). The overall research objective for the site is to develop a fundamental understanding of hydrologic conditions and contaminanttransport processes in arid regions (Andraski and Stonestrom, 1999). Geophysical methods are used to better characterize the hydrogeologic framework of the unsaturated zone through which contaminants are transported in support of the overall objective of the study. The web homepage for the Toxic Substances Hydrology Program is http://toxics.usgs.gov.

The direct-current $(\mathrm{dc})$ resistivity method is a geophysical technique that uses variations in electrical resistivity of the earth to help detect buried hydrogeologic, man-made, and geologic features. Direct-current resistivity measurements were made from May 5 through May 13, 2003 along three profiles near the ADRS using an eight-channel resistivity imaging system (model R8/IP "SuperSting" manufactured by Advanced Geosciences Inc., Austin, TX, USA). The method was done at these sites to determine if it could provide estimates on the distribution of water in the unsaturated zone beneath the ADRS and beneath the ephemeral sections of the Amargosa River channel and locations where deep percolation and active recharge may be occurring. These localized studies build on the previous regional dc resistivity work of Robert Bisdorf (2002).

\section{Purpose and Scope}

This report describes results of an initial investigation to estimate the distribution of water in the unsaturated zone and to evaluate the shallow subsurface stratigraphy near the ADRS. The geophysical method of dc resistivity was employed by 
using automated data collection with numerous electrodes. "Cross sections" of resistivity, produced by using an inversion algorithm on the field data, at the three field sites are presented and interpreted.

\section{Site Location and Description}

The three profiles used to develop cross sections of dc resistivity are within $7 \mathrm{~km}$ of the ADRS. The ADRS is at the southwest corner of a waste-storage facility in the northern Amargosa Desert (fig. 1). Receiving an average of only 10.8 centimeters $(\mathrm{cm})$ of precipitation annually, this is one of the most arid regions in the United States (Andraski and Stonestrom, 1999). Additional information concerning the ADRS and the waste-storage facility can be found at http://nevada.usgs.gov/adrs/.

The three profiles shown on figure 1 are: (1) across an interfluvial plain at the ADRS along a seismic refractionreflection line (designated SEISSTART-SEISEND); (2) across a poorly incised (distributary) section of the Amargosa River near the old Ashton town site south of the ADRS (designated ASTONSTART-ASTONEND); and across a well-incised flood plain of the Amargosa River near the aviation navigational radio beacon northwest of the ADRS (designated RADIOSTARTRADIOEND).

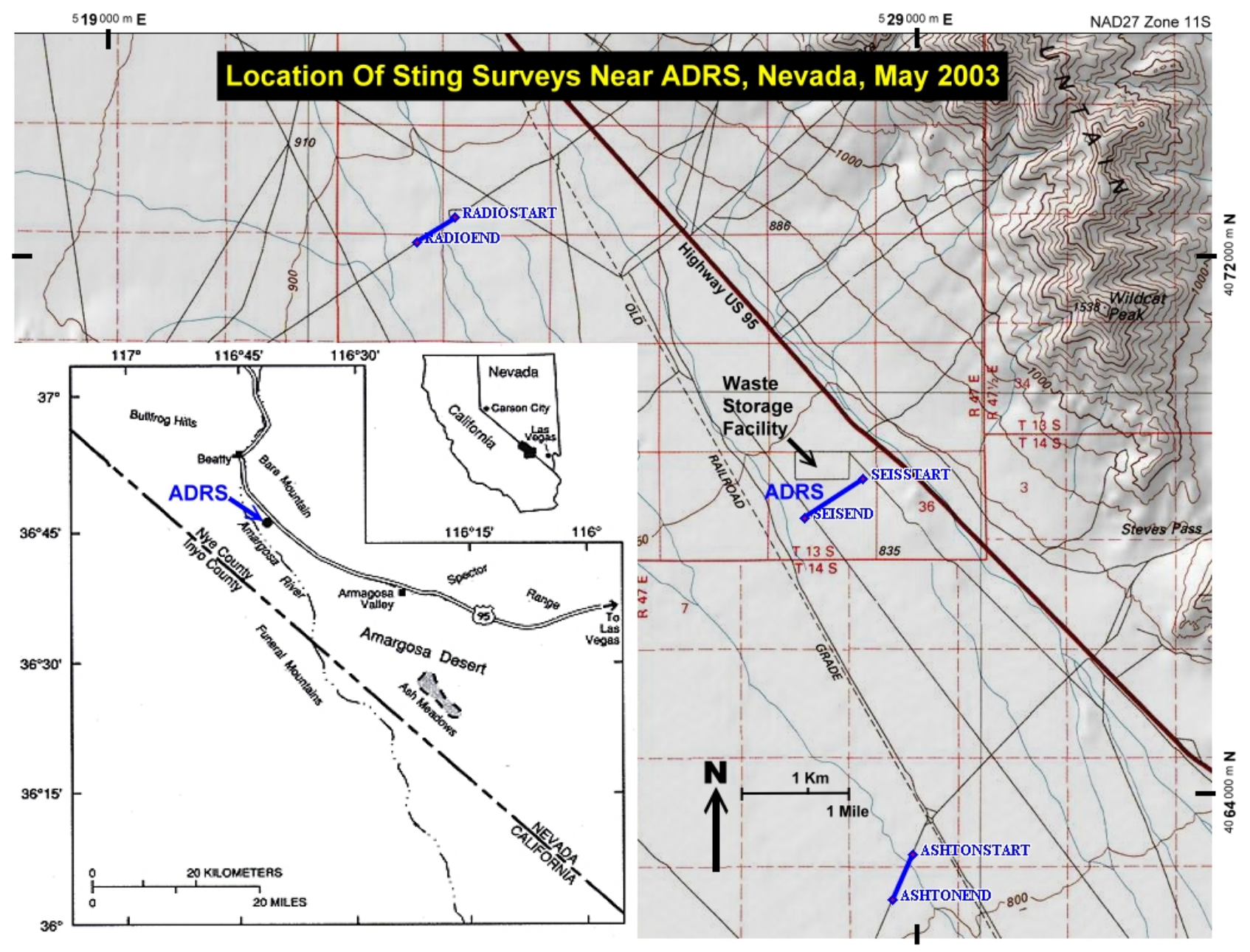

Figure 1. Locations of the Amargosa Desert Research Site (ADRS), waste-storage facility, and the three profiles for dc resistivity profiling, northern Amargosa Desert, Nevada. 


\section{Method of Investigation}

\section{Resistivity of Earth Materials}

Electrical resistivity, which is the inverse of electrical conductivity, is a fundamental property that varies in the earth with rock or sediment type, porosity, and the quality and quantity of water. Generally, electricity is conducted in the earth electrolytically by interstitial fluids (usually water) and electronically by certain materials (such as clay minerals which support cation exchange). Because of this, unsaturated zones that have high water content or water with high concentrations of dissolved solids (salts) or sediments with high clay content have lower resistivity. Resistivity usually is expressed in ohmmeters $(\Omega-\mathrm{m})$. Thorough discussions of the dc resistivity method and electrical responses of earth materials can be found in Zohdy and others (1974), Sumner (1976), and Sharma (1997).

\section{Automated dc Resistivity Profiling and Resistivity Imaging}

Electrical sounding is a method to investigate the change in earth resistivity with depth at a particular location. Horizontal electrical profiling is a method to determine lateral variations in earth resistivity within a limited depth range. Traditionally, arrangements using four electrodes (two current-transmitting electrodes and two voltage-sensing electrodes) are used for either vertical soundings or horizontal profiling. For vertical soundings, the electrodes are arranged symmetrically about a center, with increasing distances between electrodes used to explore deeper depths. For horizontal profiling, the electrode spacing and geometry are held constant and the array of four electrodes is moved along a (usually) straight path. The traditional measurement of dc resistivity has recently given way to multielectrode systems that have the capability of recording many channels of data simultaneously. Multielectrode systems allow the rapid collection of sounding and profiling measurements. Having a dense array of data allows for more detailed interpretation of changes in dc resistivity in the subsurface.

Whether using sounding or profiling techniques, an estimate of the earth resistivity is calculated by using the wellknown relation between resistivity, an electric field, and current density (called Ohm's Law), and the geometry and spacing of the current and potential electrodes. When the earth is not homogeneous and isotropic, this estimate is called the apparent resistivity, which is an average of the true resistivity in the measured section of the earth.

Multielectrode surveys were conducted along the three profiles near the ADRS using an inverse Schlumberger array. The basic setup was to insert into the Earth up to 80 electrodes a fixed distance apart, called the "a-spacing", in a line. A single measurement uses from four to ten of these electrodes simultaneously, one-half of these electrodes are on either side of a central point. The inner two electrodes carry current into the earth. The outer two to eight electrodes are used to measure the difference in electric potential in the earth. As the equipment finishes collecting data from the line of electrodes, a group of electrodes is moved from the beginning of the line to the end of the line. Data collection then continues over the areas that have not been previously measured. This method allows for the measurement of dc resistivity along long profiles without sacrificing resolution.

The dc resistivity measurements collected in the field are manipulated to obtain true resistivity with depth using a numerical inversion. The inversion routine used for the ADRS data was a "Robust inversion" included in EarthImager, which is dc resistivity inversion software sold by Advanced Geosciences Inc. (Austin, TX, USA). The Robust inversion is based on the assumption of exponential distribution of data errors and minimizes an L1-norm of combined data misfits and a model stabilizing function (Advanced Geosciences Inc., 2002). Utilizing the two-dimensional geometry of the survey line, the inversion minimizes the root mean square (RMS) error between the observed resistivity and the resistivity calculated from the inversion model. The result is a highly detailed "cross section" of resistivity corrected for changes in the elevations along the line. 


\section{Resistivity Imaging at Three Sites}

\section{Upland Interfluvial Site}

One profile was collected using 80 electrodes at the Upland Interfluvial Site near the southeast corner of the ADRS. The profile was $1,150 \mathrm{~m}$ long with a 5-meter $(\mathrm{m})$ a-spacing. Electrodes were wetted with a $\mathrm{NaCl}$ solution (1 pound per 5 gallons) to improve electrical contact with the extremely dry surface sediments. Current levels typically were on the order of 400 milliamp (mA) but were as high as $750 \mathrm{~mA}$. Two cycles of alternating positive and negative 7.2-second pulses were summed to provide average apparent resistivity and repeatability estimates. This profile had 228 electrode positions and 4,189 individual apparent resistivity values. Inversion results for this site (fig. 3) had a model data RMS error of 7.74 percent and a normalized L2 $=6.65$.

The pseudosection presentation in figure $3 \mathrm{a}$ and $3 \mathrm{~b}$ (and in figures $6 \mathrm{a}, 6 \mathrm{~b}, 9 \mathrm{a}$, and $9 \mathrm{~b}$ ) is a plotting convention. The electrode locations are drawn along the surface. In some figures this looks like a solid line because of the close spacing. The data "locations" are drawn as dots below the center of an electrode array, the middle point between the current electrodes in this case, at a depth determined by the distance between the outside electrodes in the array, regardless of whether they are current or potential electrodes. The numbers along the top of the images are distance in meters.

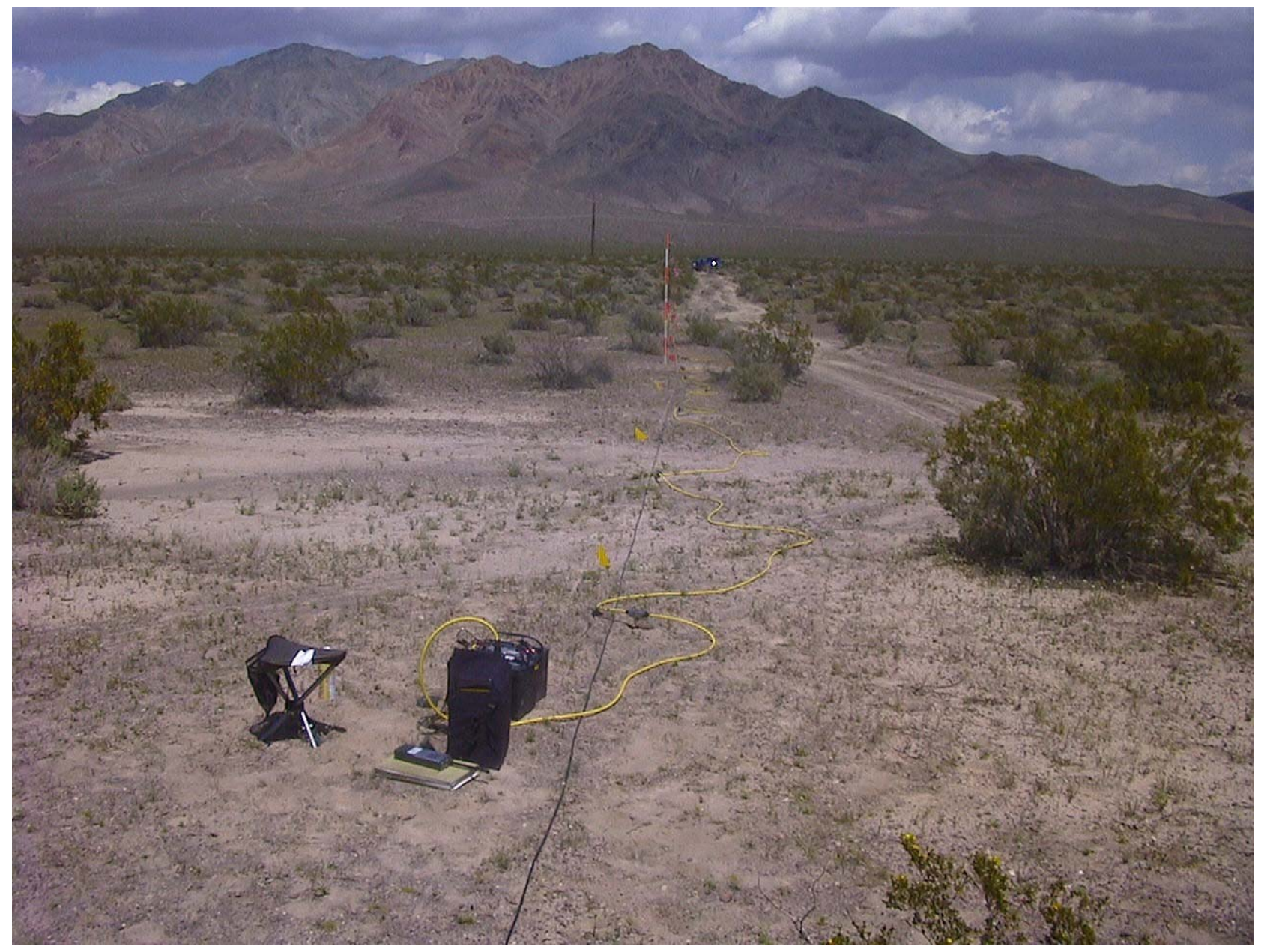

Figure 2. View of the dc resistivity profile along the seismic refraction-reflection line across the southern end of the ADRS, Amargosa Desert, Nevada. View is looking northeast toward the southern end of the Bare Mountains. Location of profile is shown on figure 1. 

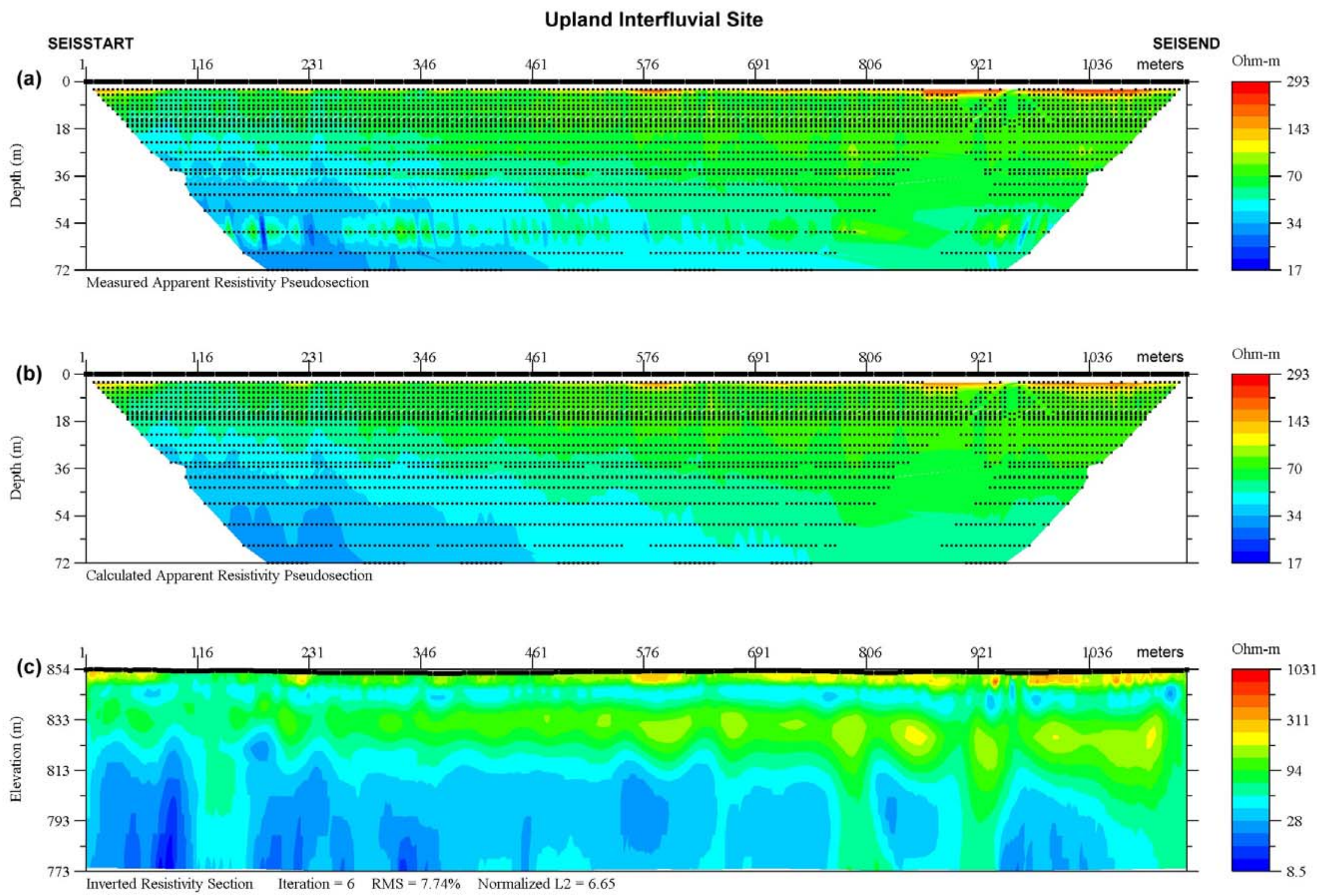

Figure 3. Resistivity imaging (collected east to west) at the upland interfluvial site near the southern end of the ADRS, Amargosa Desert, Nevada. (a) The field apparent resistivity calculations shown as a pseudosection. (b) The inversion model resistivity calculations shown as a pseudosection. (c) The resistivity cross section derived from the inversion. Location of profile is shown on figure 1. 
The resistivity cross section (fig. 4), the same as figure $3 \mathrm{c}$ except with a different color scale, shows a high-resistive interval (greater than $100 \Omega-\mathrm{m}$ ) from land surface to a depth of about $5 \mathrm{~m}$ and another high-resistive interval from about 20 to $40 \mathrm{~m}$ below land surface on the west side (right edge of profile in fig. 4). The high-resistive interval near land surface corresponds to the very dry gravel that extends from about 0.5 to $3 \mathrm{~m}$ depth beneath land surface (Fischer, 1992; Andraski, 1997). The high-resistive layer at depth corresponds to another dry gravelly interval as determined from two test holes (Prudic and others, 1997) and, according to the resistivity profile, is laterally extensive. Tritium-concentration profiles in the subsurface have peaks in both of the high-resistive intervals (Prudic and others, 1999). Based on the resistivity profile, this deeper highresistive layer becomes shallower and thins to the east (left side of profile in fig. 4). Areas of low resistivity (less than about 30 $\Omega-\mathrm{m}$ ) beneath the deeper high-resistive interval correspond to an interval of sediments that generally have higher water content than at the surface (Stonestrom and others, 1999 and David E. Prudic, U.S. Geological Survey, Carson City, Nevada, oral commun., 2003).

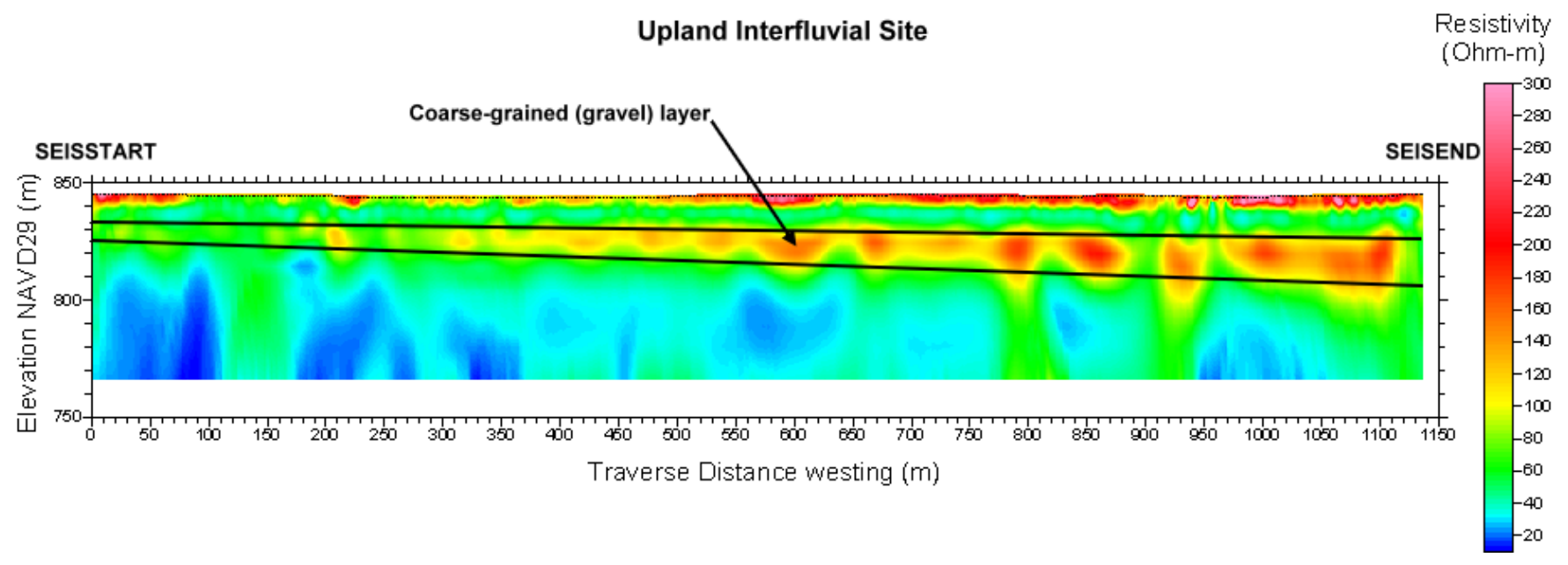

Figure 4. The resistivity cross section for the Upland Interfluvial Site at the south end of the ADRS, Amargosa Desert, Nevada. Location of profile is shown on figure 1.

\section{Poorly Incised Channel System on the Amargosa River near the Ashton Town Site}

This profile is located on the poorly incised (distributary) channel system on the Amargosa River near the town site of Ashton (fig. 1). A poorly incised distributary channel is shown on figure 5. Direct-current resistivity data were collected along two partially coincident profiles. Data were collected from 32 electrodes along each profile. One profile had an electrode spacing of $2 \mathrm{~m}$, and the other had an electrode spacing of $4 \mathrm{~m}$. The 4-m spaced electrodes went from 0 to $750 \mathrm{~m}$ along the line shown on figure 1, whereas the 2-m spaced electrodes went from 360 to $450 \mathrm{~m}$ along the same line. The closer spacing was done to improve resolution across two of the larger distributary channels, whereas the longer spacing allowed for deeper imaging. The electrode configuration resulted in a cross section that extended $30 \mathrm{~m}$ below land surface.

The electrodes were wetted with tap water to improve electrical contact with the dry surface sediments. Current levels typically were on the order of $250 \mathrm{~mA}$, but were as high as $600 \mathrm{~mA}$. Two cycles of alternating positive and negative 3.6-second pulses were summed to provide average apparent resistivity and repeatability estimates. Both profiles were combined into a single data set for inversion. The data set contained 232 electrode positions and 3,147 individual apparent resistivity values. Inversion results for this site (see fig. 6) had a model data RMS error of 5.85 percent and a normalized L2=3.80. 


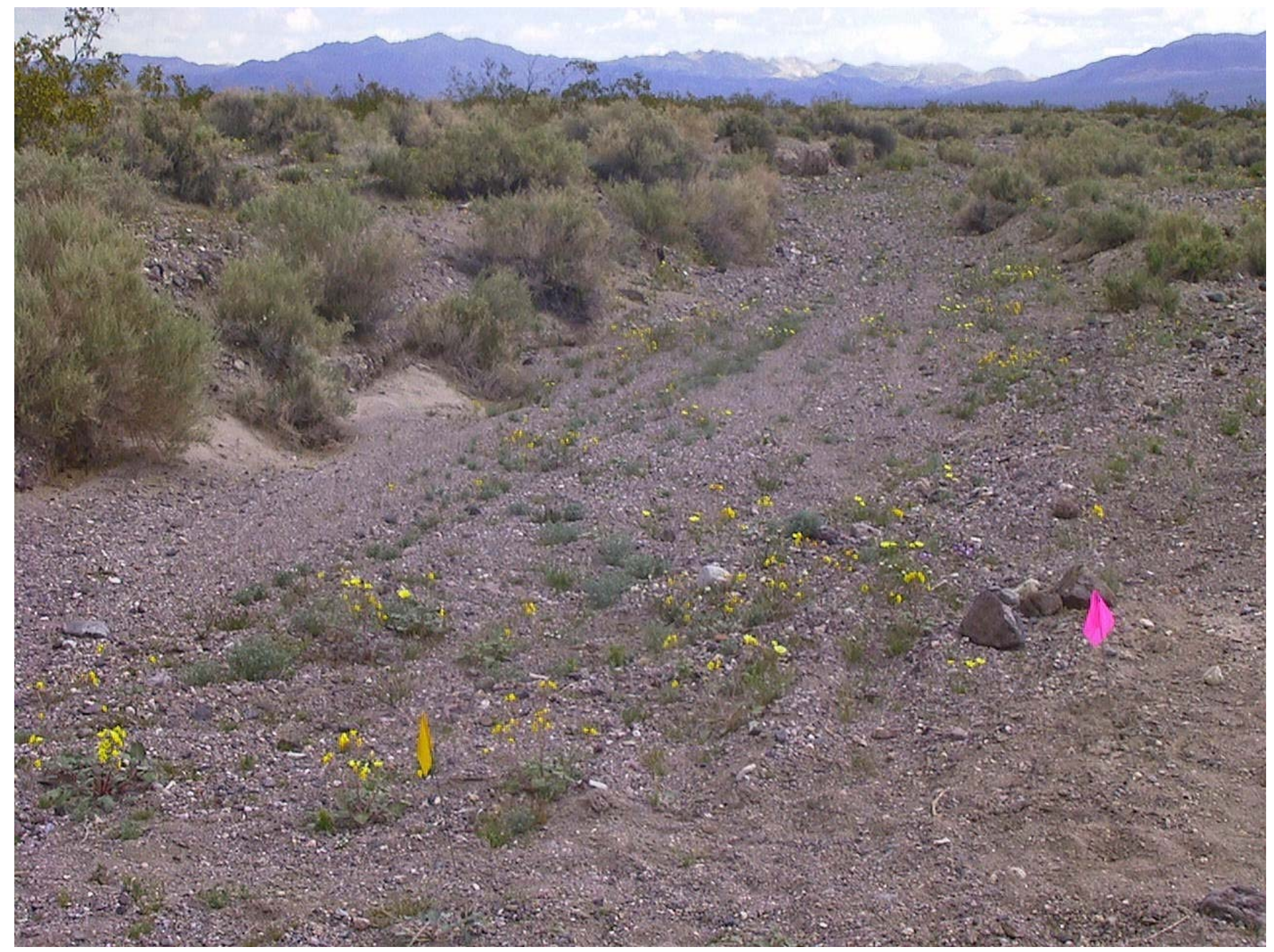

Figure 5. A view looking across the dc resistivity profile and down one of the poorly incised (distributary) channel systems of the Amargosa River near the town site of Ashton, Amargosa Desert, Nevada. Location of site is shown on figure 1. View is to the south. Red and yellow flags in foreground mark location of the two profiles along the profile.

The apparent dc resistivity cross section (fig. 7) shows two areas of higher water content that indicate deep percolation (active recharge?) below the river channels. These areas have a resistivity that is less than about $40 \Omega-\mathrm{m}$. The water content in cores collected from a test hole drilled into the channel about $30 \mathrm{~m}$ south of the profile at the $350 \mathrm{~m}$ westing indicates high water content with generally low dissolved salts to a depth of $14 \mathrm{~m}$ (Stonestrom and others, 2003). The extent of the low resistivity (high water content) with depth is limited to areas beneath the active channels (from 325 to 475 westing). Low resistivity values also are present beneath distributary channels that only receive flow during floods. Examples of such areas are the broad area east of the active channels and smaller distributary channels to the west (fig. 7). At the ground surface, the very dry, coarse sediments often have resistivity values above $150 \Omega-m$. 

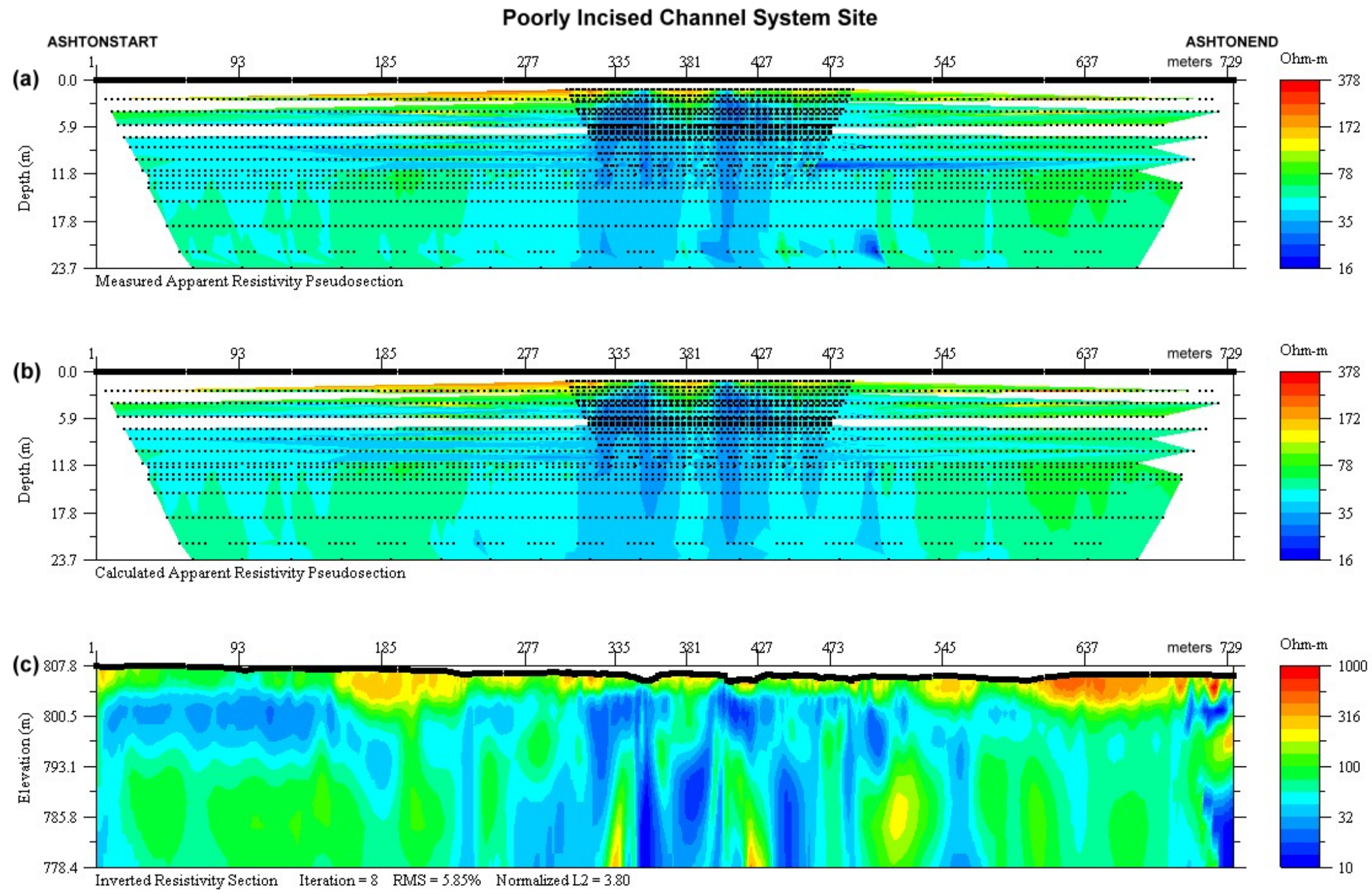

Figure 6. Resistivity imaging (collected east to west) at the poorly incised (distributary) Amargosa River channel system near the town site of Ashton, Amargosa Desert, Nevada. (a) The field apparent resistivity calculations shown as a pseudosection. (b) The inversion model resistivity calculations shown as a pseudosection. (c) The resistivity cross section derived from the inversion. Location shown on figure 1. 
Poorly Incised Channel System Site

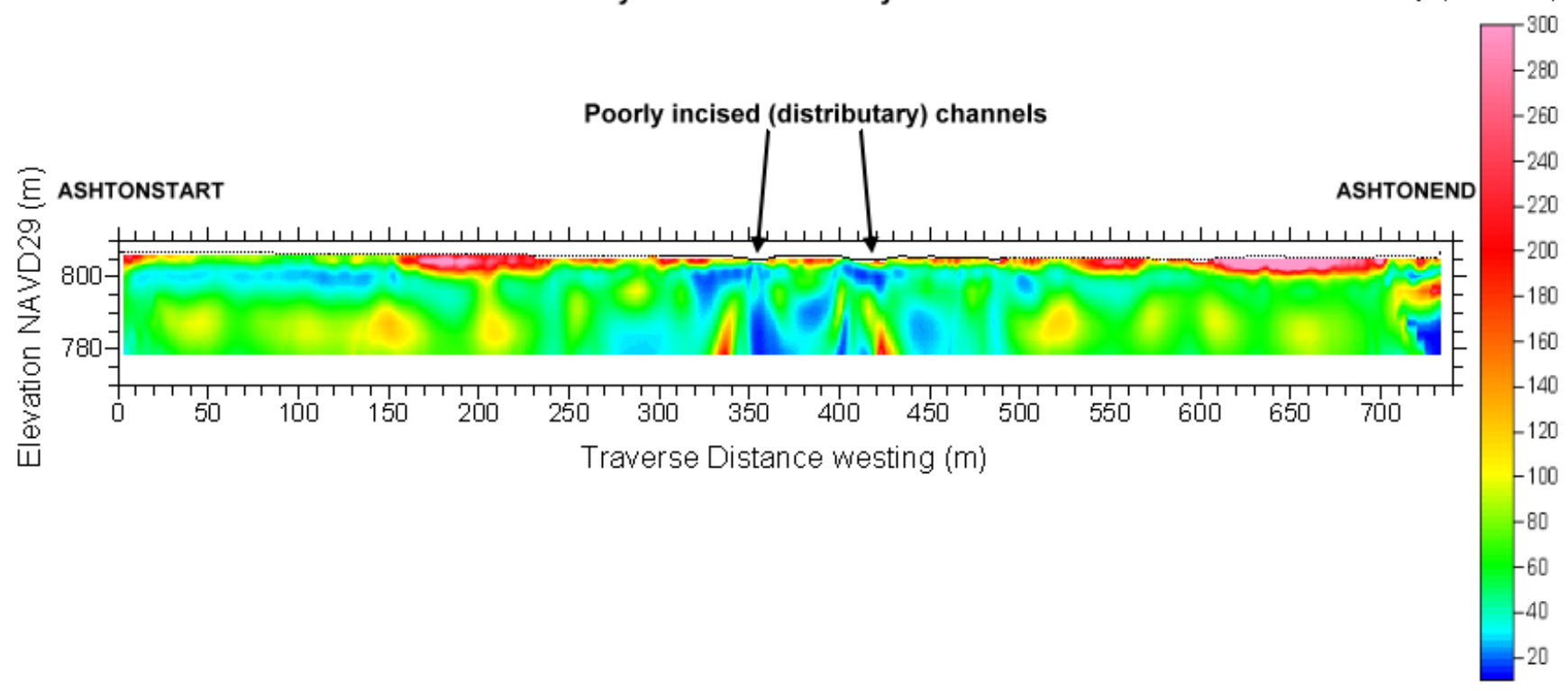

Figure 7. The resistivity cross section for the poorly incised (distributary) Amargosa River channel system near the Ashton town site south of the ADRS, Amargosa Desert, Nevada. Location shown on figure 1.

\section{Incised Flood Plain of Amargosa River near the Radio Beacon Site}

This profile is located on the well-incised flood plain of the Amargosa River near the aviation navigational radio beacon northwest of the ADRS (fig. 1). The well-incised flood plain and the active low-flow channel are shown on figure 8. Direct-current resistivity data were collected along a single profile that extended $670 \mathrm{~m}$ across the flood plain. Data were collected from 80 electrodes with a 4-m a-spacing. The electrode configuration resulted in a resistivity cross section that extended 48 meters below land surface.

The electrodes were wetted with a $\mathrm{NaCl}$ solution (1 pound per 5 gallons) to improve electrical contact with the extremely dry surface sediments. Current levels typically were on the order of $450 \mathrm{~mA}$, but were as high as $850 \mathrm{~mA}$. Two cycles of alternating positive and negative 3.6-second pulses were summed to provide average apparent resistivity and repeatability estimates. This profile contained 168 electrode positions and 3,032 individual apparent resistivity values. Inversion results for this site (fig. 9) had a model data RMS error of 12.66 percent and a normalized L2=17.79.

The resistivity cross section (fig. 10) shows an area of higher water content that indicates deep percolation (active recharge?) below the active low-flow channel along the west side of the incised flood plain. This area has a nearly continuous profile of resistivity values that are less than $40 \Omega-\mathrm{m}$. The water content in cores collected from a test hole drilled into the channel about $15 \mathrm{~m}$ south of the profile at about the 430-m westing indicate high water content with generally low dissolved salts to a depth of $14 \mathrm{~m}$ (Stonestrom and others, 2003). An extensive area of low resistivity was also determined beneath the broad area of the flood plain, and is consistent with rare but periodic inundation on the flood plain. The last time the flood plain may have been inundated is during the flood of February 1969, the largest flood of record (Stonestrom and others, 2003). The much higher resistivity of sediments near ground surface (values above $150 \Omega-\mathrm{m}$ ) along the flood plain, in contrast to the much lower values beneath the active low-flow channel (fig. 10), indicate that the flood plain has been slowly drying since the last flood and illustrates the infrequent nature of flooding on the Amargosa River. The deflection of the resistivity west of the active low-flow channel suggests that some lateral movement of moisture occurs in the sediments, but this lateral movement does not extend more than $20 \mathrm{~m}$ away from the flood plain. 


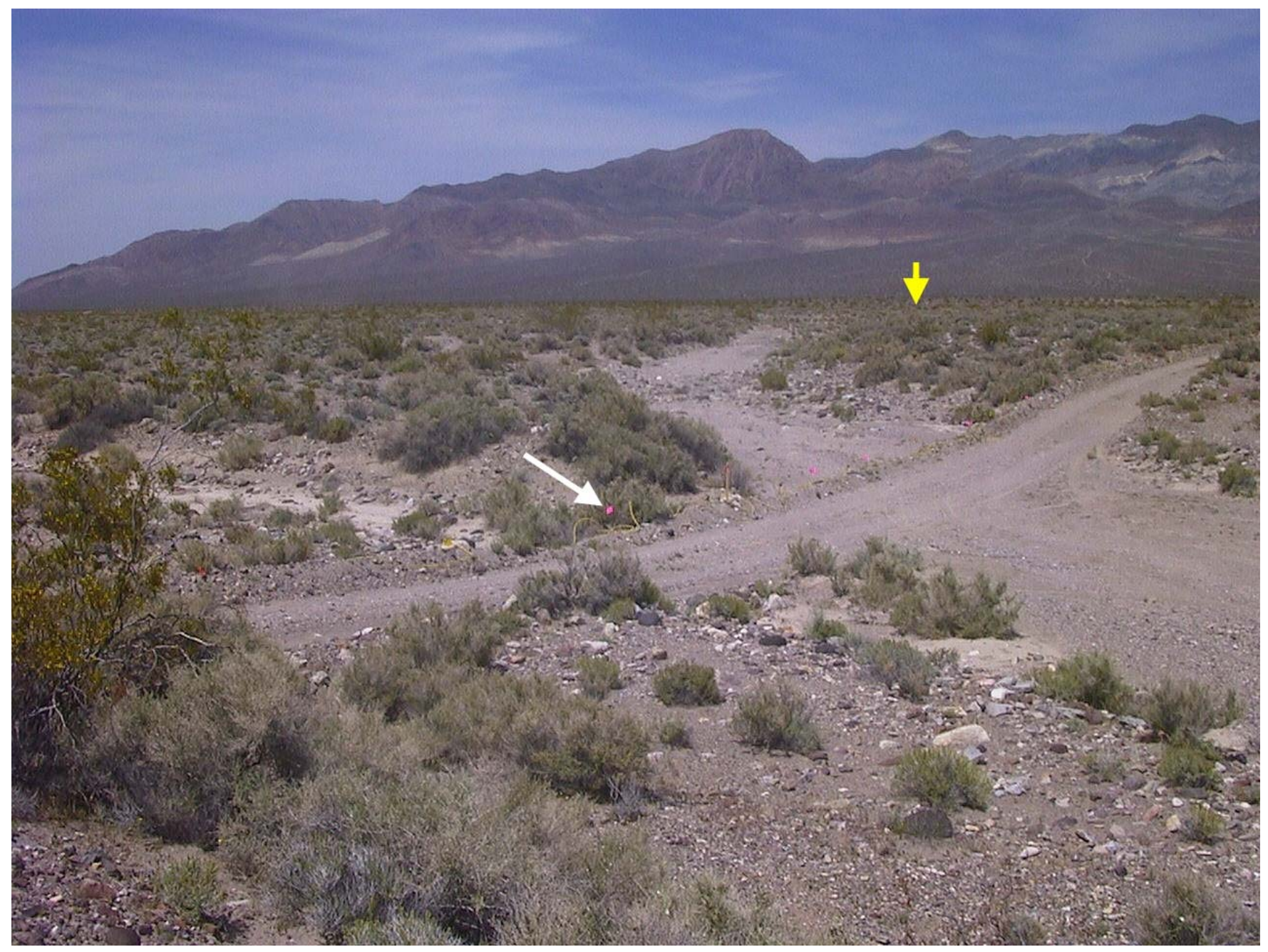

Figure 8. A view from the west side of the incised channel of the Amargosa River near the aviation navigation radio beacon northwest of the ADRS, Amargosa Desert, Nevada. Location of site is shown on figure 1. The view is looking northeast and shows the main low- flow channel of the Amargosa River. The profile for the dc resistivity profile followed the road that crosses the channel. Pink flagging (white arrow shows location of one flag) shows locations of electrodes along north side of road. Yellow arrow in middle of photograph is at the east edge of the well-incised channel of the flood plain. 


\section{Well-Incised Channel Site}
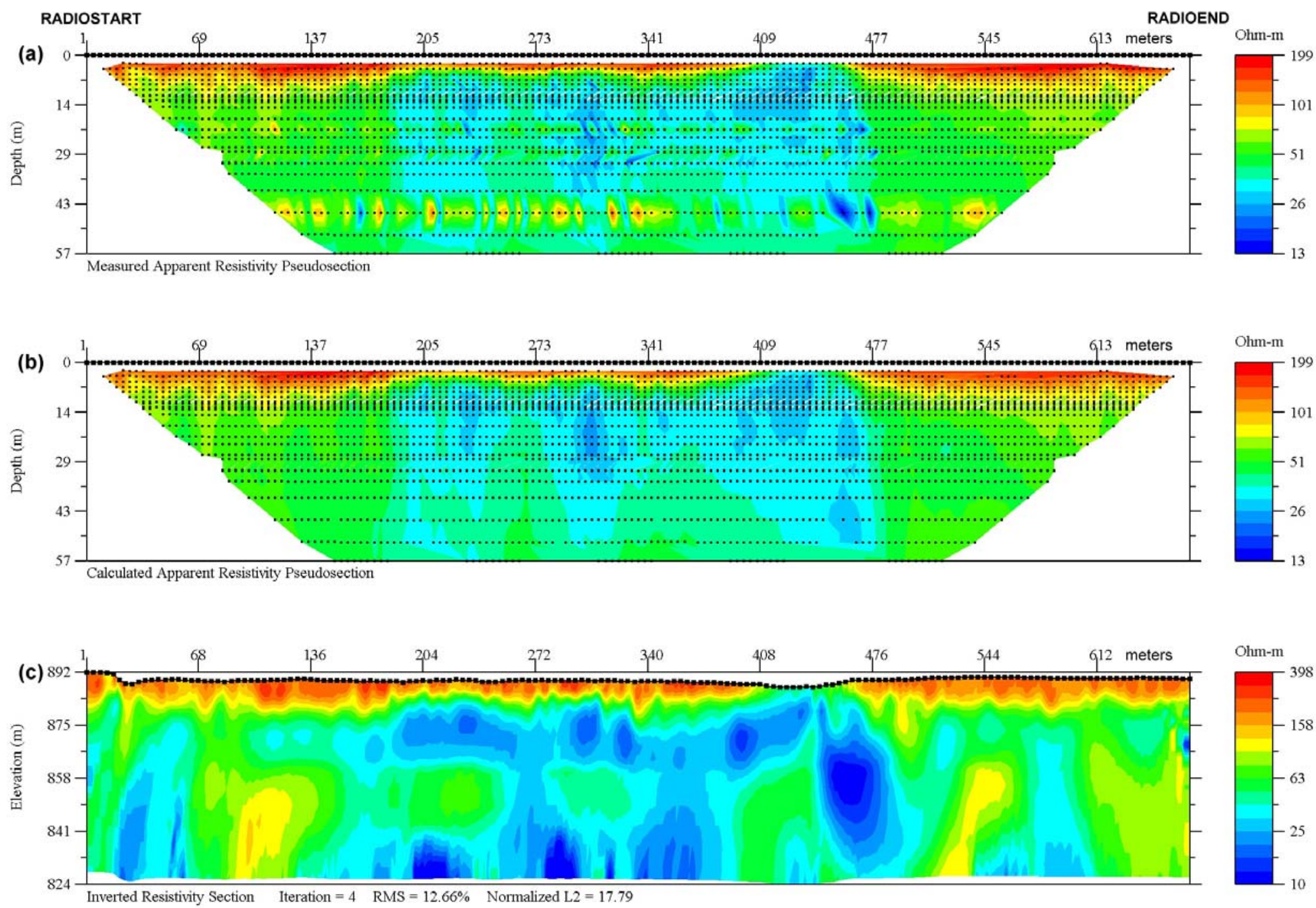

Figure 9. Resistivity imaging (collected east to west) at the well-incised flood plain of the Amargosa River near the aviation navigational radio beacon northwest of the ADRS, Amargosa Desert, Nevada. (a) The field apparent resistivity calculations shown as a pseu dosection. (b) The inversion model resistivity calculations shown as a pseudosection. (c) The resistivity cross section derived from the inversion. Location shown on figure 1. 
Well-Incised Channel Site

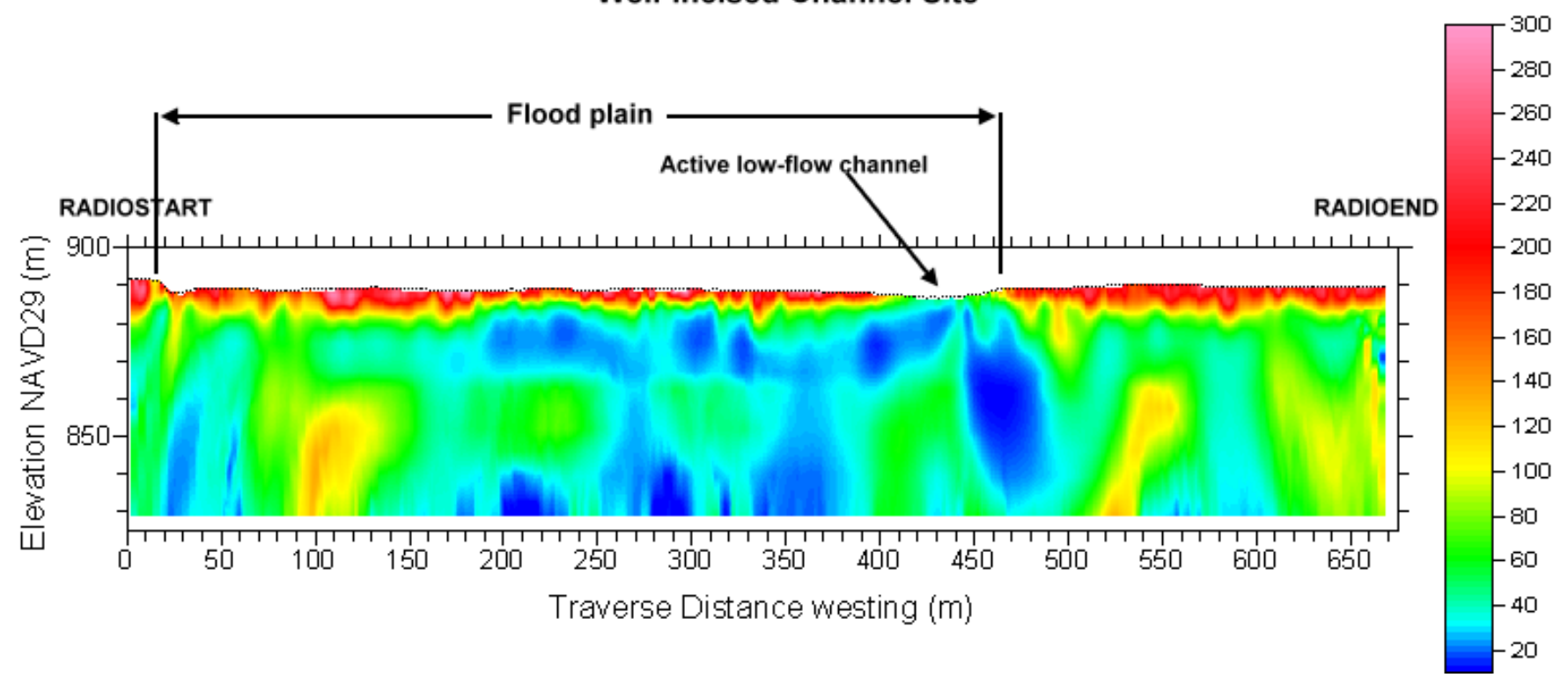

Figure 10. The resistivity cross section at the well-incised flood plain of the Amargosa River near the aviation navigational radio beacon northwest of the ADRS, Amargosa Desert, Nevada. Location is shown on figure 1.

\section{Discussion}

Multielectrode dc resistivity surveying is a practical method to image the hydrogeologic features to a depth of about 80 meters in the arid environment of the Amargosa Desert. Changes in resistivity can correlate well with changes in moisture content as well as changes in lithology. Areas of high water content and deep percolation (active recharge?) were identified beneath the ephemeral stream channels of the Amargosa River. A laterally extensive coarse-grained (gravel) layer was identified from high resistivity values in the area of the ADRS. Both the distribution of water content and coarse-grained layers are important in understanding the migration of contaminants in the unsaturated zone.

Future geophysical studies near the ADRS may include (1) performing additional resistivity surveys to map the thickness and extent of the coarse-grained (gravel) layer near 25-m depth because elevated tritium concentrations have been observed in test holes from this interval, (2) comparing resistivity survey measurements with water content determined from cores and from neutron-moisture measurements in test holes, and (3) developing mixing models that will allow the mapping of moisture content in the subsurface.

\section{Acknowledgment}

The authors thank David A. Stonestrom and David E. Prudic of the USGS Amargosa Desert Research Site Team for their interpretations of the resistivity data in terms of geologic consequences and impact, and for their thoughtful comments during the preparation and revision of this document. 


\section{Literature Cited}

Advanced Geosciences Inc., 2002, EarthImager, Version 1.0.0 2D Resistivity and IP Inversion Software Instruction Manual: Advanced Geosciences Inc., Austin, TX, 58 p.

Andraski, B.J., 1997, Soil-water movement under natural-site and waste-site conditions: A multiple-year field study in the Mojave Desert, Nevada: Water Resources Research, v. 33, n. 8, p. 1901 1916.

Andraski, B.J., and Stonestrom, D.A., 1999, Overview of research on water, gas, and radionuclide transport at the Amargosa Desert Research Site, Nevada, in Morganwalp, D.W. and Buxton, H.T., eds., U.S. Geological Survey Toxic Substances Hydrology Program Proceedings of the Technical Meeting, Charleston, South Carolina, March 8 12, 1999, v. 3, Subsurface Contamination from Point Sources: U.S. Geological Survey Water-Resources Investigations Report 994018C, p. 459 465.

Bisdorf, R.J., 2002, Schlumberger Soundings at the Amargosa Desert Research Site, Nevada, United States Geological Survey Open-File Report 02 140: United States Geological Survey, Denver, Colo., available on the web at http://pubs.usgs.gov/of/2002/ofr-02-0140/.

Fischer, J.M., 1992, Sediment properties and water movement through shallow unsaturated alluvium at an arid site for disposal of low-level radioactive waste near Beatty, Nye County, Nevada: U.S. Geological Survey Water-Resources Investigations Report 92-4032, 48 p.

Prudic, D.E., Stonestrom, D.A., and Striegl, R.G., 1997, Tritium, deuterium, and oxygen-18 in water collected from unsaturated sediments near a low-level radioactive-waste burial site south of Beatty, Nevada: U.S. Geological Survey WaterResources Investigations Report 97-4062, 23 p.

Prudic, D.E., Striegl, R.G., Healy, R.W., Michel, R.L., and Hass, Herbert, 1999, Tritium and 14C concentrations in unsaturatedzone gages at test hole UZB-2, Amargosa Desert Research Site, 1994 98, in Morganwalp, D.W. and Buxton, H.T., eds., U.S. Geological Survey Toxic Substances Hydrology Program -- Proceedings of the Technical Meeting, Charleston, South Carolina, March 8 12, 1999, v. 3, Subsurface Contamination from Point Sources: U.S. Geological Survey Water-Resources Investigations Report 99-4018C, p. 475 483.

Sharma, P.V., 1997, Environmental and Engineering Geophysics: Cambridge University Press, Cambridge, United Kingdom, 475 p.

Stonestrom, D.A., Prudic, D.E., and Striegl, R.G., 1999, Isotopic composition of water in a deep unsaturated zone beside a radioactive-waste disposal area near Beatty, Nevada, in Morganwalp, D.W. and Buxton, H.T., eds., U.S. Geological Survey Toxic Substances Hydrology Program Proceedings of the Technical Meeting, Charleston, South Carolina, March 8 12, 1999, v. 3, Subsurface Contamination from Point Sources: U.S. Geological Survey Water-Resources Investigations Report 99-4018C, p. 475 483.

Stonestrom, D.A., Prudic, D.E., Laczniak, R.J., Akstin, K.C., Boyd, R.A., and Henkelman, K.K., 2003, Estimates of deep percolation beneath native vegetation, irrigated fields, and the Amargosa River Channel, Amargosa Desert, Nye County, Nevada: U.S. Geological Survey Open-File Report 03-104, 83 p.

Sumner, J.S., 1976, Principles of Induced Polarization for Geophysical Exploration: Elsevier Scientific Publishing Company, Amsterdam, Netherlands, $277 \mathrm{p}$.

Zohdy, A.A.R., Eaton, G.P., and Mabey, D.R., 1974, Application of Surface Geophysics to Ground-Water Investigations, Techniques of Water-Resources Investigations of the United States Geological Survey, Book 2, Chapter D1: United States Geological Survey, Denver, Colo., 116 p. 